(C) 2021, The Authors. Published by Elsevier Inc. and Fass Inc. on behalf of the American Dairy Science Association ${ }^{\circledR}$. This is an open access article under the CC BY-NC-ND license (http://creativecommons.org/licenses/by-nc-nd/4.0/).

\title{
Invited review: The future of selection decisions and breeding programs: What are we breeding for, and who decides?
}

\author{
John B. Cole, ${ }^{1 *} \dagger$ ๑ João W. Dürr, ${ }^{2}$ and Ezequiel L. Nicolazzi ${ }^{2}$ \\ ${ }^{1}$ Animal Genomics and Improvement Laboratory, Agricultural Research Service, United States Department of Agriculture (USDA), Beltsville, \\ MD 20705-2350 \\ ${ }^{2}$ Council on Dairy Cattle Breeding, 4201 Northview Drive, Suite 302, Bowie, MD 20716
}

\begin{abstract}
Genetic selection has been a very successful tool for the long-term improvement of livestock populations, and the rapid adoption of genomic selection over the last decade has doubled the rate of gain in some populations. Breeding programs seek to identify genetically superior parents of the next generation, typically as a function of an index that combines information about many economically important traits into a single number. In the United States, the data that drive this system are collected through the national dairy herd improvement program that began more than a century ago. The resulting information about animal performance, pedigree, and genotype is used to compute genomic evaluations for comparing and ranking animals for selection. However, the full expression of genetic potential requires that animals are placed in environments that can support such performance. The Agricultural Research Service of the US Department of Agriculture and the Council on Dairy Cattle Breeding collaborate to deliver state-of-the-art genomic evaluations to the dairy industry. Today, most breeding stock are selected and marketed using the net merit dollars $(\mathrm{NM} \$)$ selection index, which evolved from 2 traits in 1926 (milk and fat yield) to a combination of 36 individual traits following the last $\mathrm{NM} \$$ update in 2018. Updates to $\mathrm{NM} \$$ require the estimation of many different values, and it can be difficult to achieve consensus from stakeholders on what should be added to, or removed from, the index at each review, and how those traits should be weighted. Over time, the majority of the emphasis in the index has shifted from yield traits to fertility, health, and fitness traits. Phenotypes for some of these new traits are difficult or expensive
\end{abstract}

Received October 13, 2020.

Accepted January 3, 2021.

${ }^{*}$ Current address: URUS Group LP, 2418 Crossroads Drive, Suite 3600, Madison, WI 53718.

†Corresponding author: john.b.cole@gmail.com to measure, or require changes to on-farm habits that have not been widely adopted. This is driving interest in sensor-based systems that provide continuous measurements of the farm environment, individual animal performance, and detailed milk composition. There is also a need to capture more detailed data about the environment in which animals perform, including information about feeding, housing, milking systems, and infectious and parasitic load. However, many challenges accompany these new technologies, including a lack of standardization or validation, need for high-speed internet connections, increased computational requirements, and interpretations that are often not backed by direct observations of biological phenomena. This work will describe how US selection objectives are developed, as well as discuss opportunities and challenges associated with new technologies for measuring and recording animal performance.

Key words: breeding programs, genetic improvement, selection objectives, total merit indices

\section{INTRODUCTION}

Selection indices are essential tools in modern dairy cattle breeding because they enable information about many traits to be combined into a single value for ranking animals and making selection decisions. The ideal breeding objective for dairy cattle remains a popular topic, even if consensus is elusive, and is frequently discussed in the scientific and popular literature (e.g., Hazel et al., 1994; Philipsson et al., 1994; VanRaden, 2004; Miglior et al., 2005; Shook, 2006; Miglior et al., 2017; Cole and VanRaden, 2018; Binversie, 2019; Dechow, 2020; Schmidt, 2020). There is no single selection objective that is ideal for all populations, or all herds within a population, but there is a general set of principles that should be followed when developing an index (e.g., Cameron, 1997).

Historically, selection indices in the United States were developed by the United States Department of Agriculture (USDA) and by purebred dairy cattle 
associations (PDCA). Input has also been provided by scientists at land-grant universities and technical experts at breeding companies, using data available through the national milk recording system and breed type appraisal programs. Proposed indices from the USDA were typically reviewed by groups of experts, and information about the derivation of the indices was published in technical and trade publications, ensuring confidence in the values because of that review process. Recently, genetic evaluations for novel traits and new selection indices have been computed and distributed by companies such as GENEX and Zoetis. Both of these organizations publish their own indices, which include a combination of traits from the Council on Dairy Cattle Breeding (CDCB) evaluations and their own proprietary traits (i.e., hoof health in the case of GENEX, and cow and calf health traits in the case of Zoetis). This provides farmers with new tools and may drive demand for new phenotypes, but transparent review processes are often lacking. Correlations among indices are generally strong (T. J. Lawlor Jr., Holstein Association USA, Brattleboro, VT; personal communication), and in such cases, it is unclear if new tools provide new information or serve only as marketing tools.

This paper will describe how decisions about selection indices are made in the United States, discuss traits that may be included in future changes to existing indices, and identify opportunities associated with new technologies for recording animal performance. Although the focus is on the US dairy sector, examples from other countries are discussed when appropriate.

\section{DEVELOPMENT OF SELECTION OBJECTIVES}

\section{Who Are the Participants in the US Dairy Sector?}

To explain how selection decisions are made, we must briefly review the stakeholders in the process (Wiggans et al., 2017; Figure 1). The Animal Genomics and Improvement Laboratory is part of the Agricultural Research Service, USDA's in-house research arm, and was responsible for the development of the indices shown in Table 1 (sometimes under other laboratory names due to Agricultural Research Service organizational changes). The CDCB operates the national genetic evaluation system and maintains the national cooperator database. The CDCB board includes representatives from all key industry participants, including the National Dairy Herd Information Association (NDHIA), Dairy Records Processing Centers, the National Association of Animal Breeders, and the PDCA. The field service organizations and milk testing laboratories that operate the national milk recording program are represented by
NDHIA; the organizations that aggregate and distribute milk testing data and provide herd management information are represented by the Dairy Records Processing Centers; the AI companies, who own most of the bulls and many elite females, are represented by the National Association of Animal Breeders; and the breeders, who own most of the elite cattle, are represented by the PDCA. In addition, CDCB has several advisory groups that include farmers, researchers, and allied industry personnel that review and provide feedback on data quality and proposed changes to the genetic evaluation system. Scientists from the land-grant universities provide valuable technical expertise to the Animal Genomics and Improvement Laboratory and CDCB, both as individual consultants and through the SCC-084 Multistate Research Coordinating Committee and Information Exchange Group. This group meets annually to share results and plan future research on selection and mating strategies to improve dairy cattle performance, efficiency, and longevity. All of these participants in the national dairy improvement program have opportunities to influence the selection indices adopted by CDCB, some directly, and others indirectly.

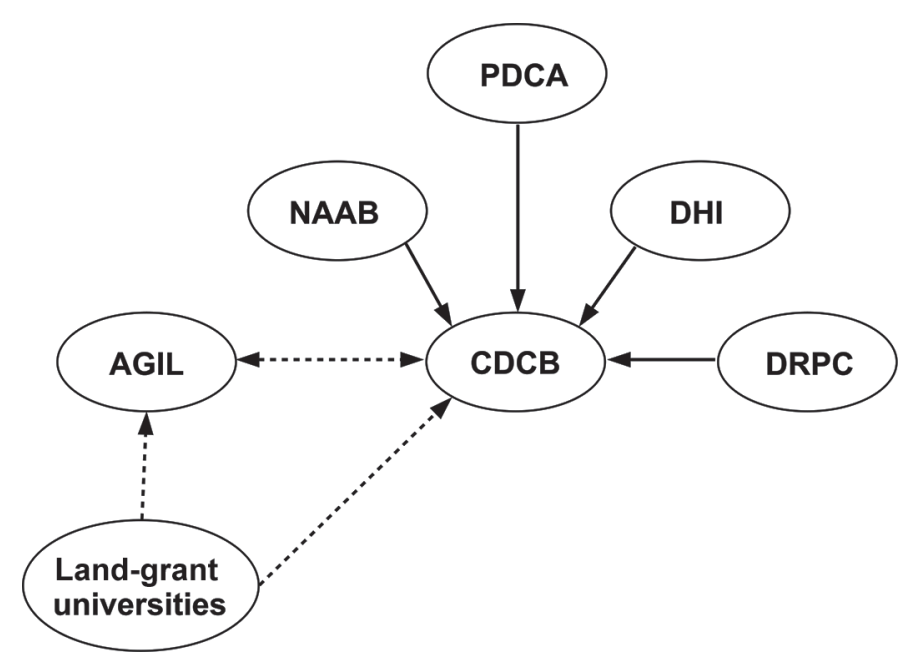

Figure 1. The general structure of the US dairy cattle improvement sector. Solid lines indicate board membership in an organization, and broken (dashed) lines represent advisory relationships. AGIL = Animal Genomics and Improvement Laboratory, Agricultural Research Service, United States Department of Agriculture (constructs the index) CDCB $=$ Council on Dairy Cattle Breeding (operates the national genetic evaluation system and maintains the national cooperator database); DRPC $=$ Dairy Records Processing Centers (aggregate and distribute milk testing data and provide herd management information); NAAB = National Association of Animal Breeders (represents breeding companies); DHI = Dairy Herd Improvement (oversees the national milk recording program); PDCA $=$ Purebred Dairy Cattle Associations (represents breeders). Scientists at the land-grant universities provide technical expertise. 
In addition to the organizations with direct representation on the CDCB board, there are several entities that participate in the collection and transfer of genomic information (Figure 2). The genomic nominators are responsible for collecting DNA samples from the animal owner, providing CDCB with information about the animals sampled, and transferring the DNA samples to the genotyping laboratory. The genotyping laboratory extracts DNA from samples, prepares SNP genotypes, provides summary information back to the nominator, and transfers the genotypes to the CDCB. Genomic evaluations are sent from the CDCB to the nominators, and on to the records providers. Both the nominators and laboratories must meet quality certification guidelines before they are permitted to participate in the system, and their performance is audited on an annual basis.

\section{How Are Decisions About Selection Criteria Made?}

How Are the Index Weights Determined? Selection indices must be periodically updated to include new traits and reflect changing economic conditions, as well as changing genetic parameters between and among traits. From the development of the first USDA index (Norman and Dickinson, 1971) until the present (VanRaden et al., 2018), a collaborative model has been used to propose and adopt changes to the indices. Although an argument can be made that changes should be driven strictly by mathematics - and we are sympathetic to this position - the reality is that tools will not be adopted unless the intended users perceive value in the tool. The net merit dollars (NM\$) weights are primarily based on selection index theory, with fine-tuning based on consensus expert opinion, which reflects the well-known challenge of computing index weights (Freeman, 1984). It is also more difficult to compute the incomes and expenses associated with traits in the index than the textbooks suggest, and input from the field is very helpful in that regard. Our experience over the last $50 \mathrm{yr}$ suggests that collaboration not only drives increased adoption of the indices, it also builds support for other communal efforts, such as the recording of new phenotypes so that they may eventually be included in the index.

Who Owns the Index? Responsibility for the national cooperators database and the genetic evaluation system was passed from USDA to CDCB in 2013, but $\mathrm{NM} \$$ and its companion indices (cheese merit, fluid merit, and grazing merit; VanRaden, 2000; Gay et al., 2014) require both index weights and genetic values to compute. When an index is owned by a PDCA or an AI company, it is clear who has the authority to make changes and the responsibility for distributing the calculations. In the case of NM\$, USDA and CDCB share these roles: USDA is responsible for construction of the index, and CDCB provides the data needed to calculate and distribute the values. Both organizations

Table 1. Traits included in United States Department of Agriculture selection indices ${ }^{1}$ and the relative emphasis placed on each, 1971-2018 (Cole and VanRaden, 2018)

\begin{tabular}{|c|c|c|c|c|c|c|c|c|c|c|c|}
\hline \multirow[b]{2}{*}{ Trait $^{2}$} & \multicolumn{11}{|c|}{ Relative emphasis on trait (\%) } \\
\hline & $\begin{array}{c}\mathrm{PD} \$ \\
(1971)\end{array}$ & $\begin{array}{l}\text { MFP\$ } \\
(1976)\end{array}$ & $\begin{array}{c}\mathrm{CY} \$ \\
(1984)\end{array}$ & $\begin{array}{c}\text { NM\$ } \\
(1994)\end{array}$ & $\begin{array}{c}\text { NM\$ } \\
(2000)\end{array}$ & $\begin{array}{c}\text { NM\$ } \\
(2003)\end{array}$ & $\begin{array}{c}\text { NM\$ } \\
(2006)\end{array}$ & $\begin{array}{c}\text { NM\$ } \\
(2010)\end{array}$ & $\begin{array}{l}\text { NM\$ } \\
(2014)\end{array}$ & $\begin{array}{c}\text { NM\$ } \\
(2017)\end{array}$ & $\begin{array}{c}\text { NM\$ } \\
(2018)\end{array}$ \\
\hline Milk & 52 & 27 & -2 & 6 & 5 & 0 & 0 & 0 & -1 & -1 & -1 \\
\hline Fat & 48 & 46 & 45 & 25 & 21 & 22 & 23 & 19 & 22 & 24 & 27 \\
\hline Protein & - & 27 & 53 & 43 & 36 & 33 & 23 & 16 & 20 & 18 & 17 \\
\hline PL & - & - & - & 20 & 14 & 11 & 17 & 22 & 19 & 13 & 12 \\
\hline SCS & - & - & - & -6 & -9 & -9 & -9 & -10 & -7 & -7 & -4 \\
\hline $\mathrm{UC}$ & - & - & - & - & 7 & 7 & 6 & 7 & 8 & 7 & 7 \\
\hline FLC & - & - & - & - & 4 & 4 & 3 & 4 & 3 & 3 & 3 \\
\hline BWC & - & - & - & - & -4 & -3 & -4 & -6 & -5 & -6 & -5 \\
\hline DPR & - & - & - & - & - & 7 & 9 & 11 & 7 & 7 & 7 \\
\hline $\mathrm{SCE}$ & - & - & - & - & - & -2 & - & - & - & - & - \\
\hline DCE & - & - & - & - & - & -2 & - & - & - & - & - \\
\hline $\mathrm{CA} \$$ & - & - & - & - & - & - & 6 & 5 & 5 & 5 & 5 \\
\hline $\mathrm{HCR}$ & - & - & - & - & - & - & - & - & 1 & 1 & 1 \\
\hline CCR & - & - & - & - & - & - & - & - & 2 & 2 & 2 \\
\hline LIV & - & - & - & - & - & - & - & - & - & 7 & 7 \\
\hline HTH\$ & - & - & - & - & - & - & - & - & - & - & 2 \\
\hline
\end{tabular}

${ }^{1} \mathrm{PD} \$=$ Predicted Difference Dollars (Dickinson et al., 1971); MFP $\$=$ Milk-Fat-Protein Dollars (Norman et al., 2010); CY $\$=$ Cheese Yield Dollars (Norman, 1986); NM $\$=$ Lifetime Net Merit Dollars (VanRaden and Wiggans, 1995).

${ }^{2} \mathrm{PL}=$ productive life; $\mathrm{UC}=$ udder composite; FLC $=$ feet and legs composite; BWC = body weight composite; DPR $=$ daughter pregnancy rate; $\mathrm{SCE}=$ sire (direct) calving ease; $\mathrm{DCE}=$ daughter (maternal) calving ease; $\mathrm{CA} \$=$ calving ability dollars; HCR = heifer conception rate; $\mathrm{CCR}=$ cow conception rate; $\mathrm{LIV}=$ cow livability; $\mathrm{HTH} \$=$ health dollars. 


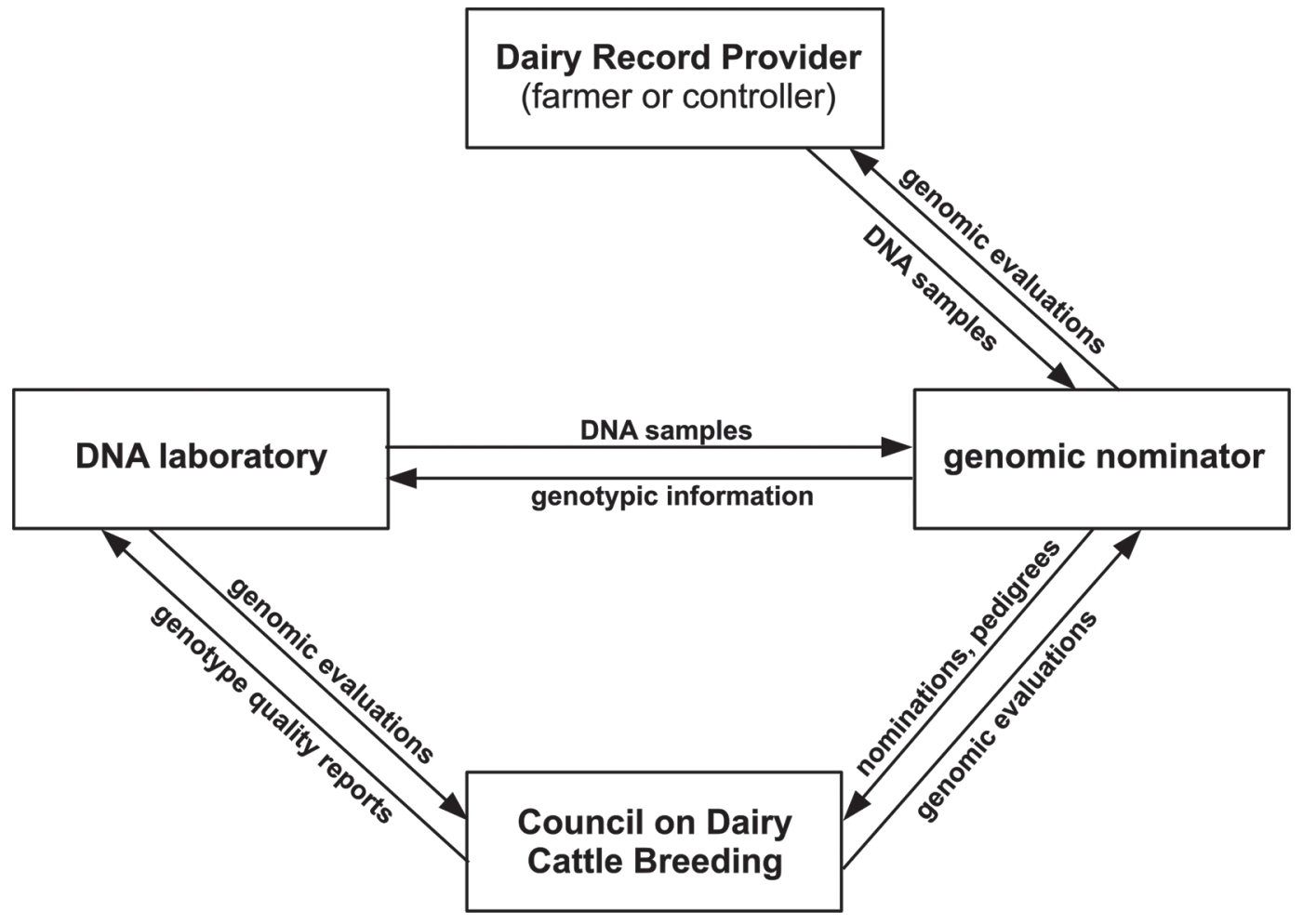

Figure 2. Flow of information among participants in the national genomic evaluation system.

have input into the evolution of the index, but neither owns it. Lifetime net merit was initially developed by USDA scientists (VanRaden and Wiggans, 1995), but it has remained relevant because of the USDA-CDCB partnership. The success of $\mathrm{NM} \$$ has not prevented other organizations from developing their own selection tools, and farmers have many indices from which to choose if $\mathrm{NM} \$$ does not meet their expectations.

How Do We Validate Our Indices? Selection indices are constructed using many calculations based on a substantial body of scientific theory (e.g., Hazel et al., 1994). Complex traits, such as longevity, remain difficult to model properly, and there is some disparity between management practices in the field and optimal economic strategies (Schmitt et al., 2019; De Vries, 2020). It can be difficult to confirm that realized selection gains are consistent with index predictions, but some recent reports show that animals with greater genetic merit are more profitable than their contemporaries with lower rankings. In the United States, scientists from Zoetis and the University of Pennsylvania recently showed that cows in the top quartile for the Dairy Wellness Profit index had greater lifetime profit than herdmates in lower quartiles (Fessenden et al., 2020). The lack of farm-level income and expense data in the national cooperator database makes it dif- ficult to perform routine validation of the index, but collaboration with projects such as the Dairy Profit Monitor program at Cornell University (https://cals .cornell.edu/pro-dairy/our-expertise/business/dairy -profit-monitor) could support such an effort.

\section{How Have Selection Indices Evolved Over Time?}

What Traits Are in the Index? The emphasis placed on each trait in each revision of the selection index is shown in Table 1, and the rate at which new traits are added to the index has increased considerably in recent years. This represents changes in dairy economics, an improved understanding of the biology of the cow, and greater ease of collecting and transferring data. The first selection index published by USDA was the Predicted Difference Dollars index, which included information about milk and fat production (Norman and Dickinson, 1971). Although it was recognized at the time that other traits might have economic importance, milk and fat were the only traits with enough phenotypic information available to support genetic evaluations. Protein yield was added to Predicted Difference Dollars in 1976 to produce the Milk-Fat-Protein Dollars index (Norman et al., 1979), and an index for cheese yield was developed in 1984 (Norman, 1986). 
This was the status quo until 1994, when productive life and SCS were combined with the yield traits to produce the first iteration of the Lifetime Net Merit index (VanRaden and Wiggans, 1995).

Although the combination of fitness, conformation, and production traits included in the first version of $\mathrm{NM} \$$ in 1994 set it apart from most of its international competitors, the Scandinavian countries began recording health and fertility data in the 1960s and computing genetic evaluations for those traits in the 1970s (Philipsson and Lindhé, 2003). Their experience showed that selection objectives that include traits with low heritabilities can produce worthwhile gains in cow health and fertility. Leitch (1994) reviewed 19 contemporary selection indices and found that only 2 (Danish S-Index and US NM\$) included mastitis resistance, 1 included fertility (Danish S-Index), and 1 included productive life (US NM\$). In a review based on an independent survey, Philipsson et al. (1994) identified several other countries' indices (Finland, Norway, Slovenia, and Sweden) that also included fitness traits. When Miglior et al. (2005) revisited the subject a decade later, each of the 17 indices reviewed included 1 or more fitness traits as part of the selection criterion. This trend toward the inclusion of more fitness traits in total merit indices has continued (Cole and VanRaden, 2018), and it is now more remarkable when an index does not include such traits than when it does.

There Is No Universal Standard. It is tempting to assume that it is possible to define a universal total merit index, but that is not possible because every farmer operates in a slightly different economic and environmental setting than their neighbors. In theory, every farm should actually use its own selection index that is customized to its financial situation and business objectives (Gjedrem, 1972). In practice, farms with similar operating and financial characteristics can use the same index with little loss of efficiency. It is also difficult to assign direct economic values to some traits, most notably conformation traits. Different breeders have different goals, which can affect their breeding programs. A commercial dairy that derives its income principally from the sale of milk solids will have different incomes and expenses than a seedstock breeder who also sells embryos and elite germplasm, and they may benefit from using different indices. Lifetime net merit is explicitly developed for use by commercial dairy farmers (VanRaden, 2004), and Holstein Association USA's Total Performance Index is intended for use by registered cattle breeders who often sell genetics as well as milk.

More than 1 index is needed because farmers sell their products into different markets (e.g., VanRaden,
2000), have different personal preferences (e.g., MartinCollado et al., 2015), and strategies for maximizing profit vary (e.g., Berry et al., 2019). As noted earlier, the $\mathrm{CDCB}$ publishes 4 separate indices (lifetime net merit, fluid merit, cheese merit, and grazing merit) to provide farmers with options that best match their needs. The strategy of providing multiple indices to its farmers is certainly not unique to the United States For example, when the Australian Dairy Herd Improvement Scheme (now DataGene) revised the Australian Profit Ranking index in 2016, they replaced it with 3 new indices (Byrne et al., 2016). The Balanced Performance Index, Health Weighted Index, and Type Weighted Index allow their farmers to focus on trait groups that are most important to them within a technically sound framework.

Are There Too Many Indices Already? The last several years have seen the development of many new selection indices marketed to commercial dairy farmers. In contrast to $\mathrm{NM} \$$ and indices published by PDCA, many of these new indices are promoted by breeding companies as a means of differentiating their products. Several selection indices currently available to US dairy farmers are shown in Table 2, although this is not an exhaustive list (some organizations do not make the details of their index publicly available). These tools include indices developed by USDA, PDCA (e.g., American Jersey Cattle Association), and commercial organizations (e.g., Zoetis). In general, most indices are similar in that they are seeking to find a balance between productivity (the direct source of much farm income) and fitness traits (often a source of direct costs). Direct comparisons are challenging because some indices are available only for bulls marketed by the publisher of the index. Most differences among indices are due to the inclusion of different sets of traits, or to the differential weighting of such traits in the index. Some companies develop proprietary evaluations to differentiate their offerings from those of their competitors. Correlations among these indices generally are very strong, and there is minimal reranking of bulls when moving from one index to another (T. J. Lawlor Jr., Holstein Association USA, Brattleboro, VT; personal communication). However, farmers may not be able to clearly describe differences between each index, providing some opportunities for confusion. There also is concern that marketers may be over-stating the importance of the differences between the indices.

Are Selection Indices Responsible for Reducing Diversity in Some Breeds? It is tempting to place the blame for the ongoing loss of genetic diversity in US Holsteins (e.g., Maltecca et al., 2020) on breeders who avidly pursue high-index animals, but 


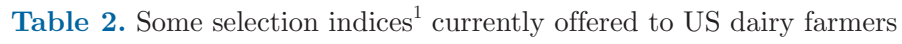

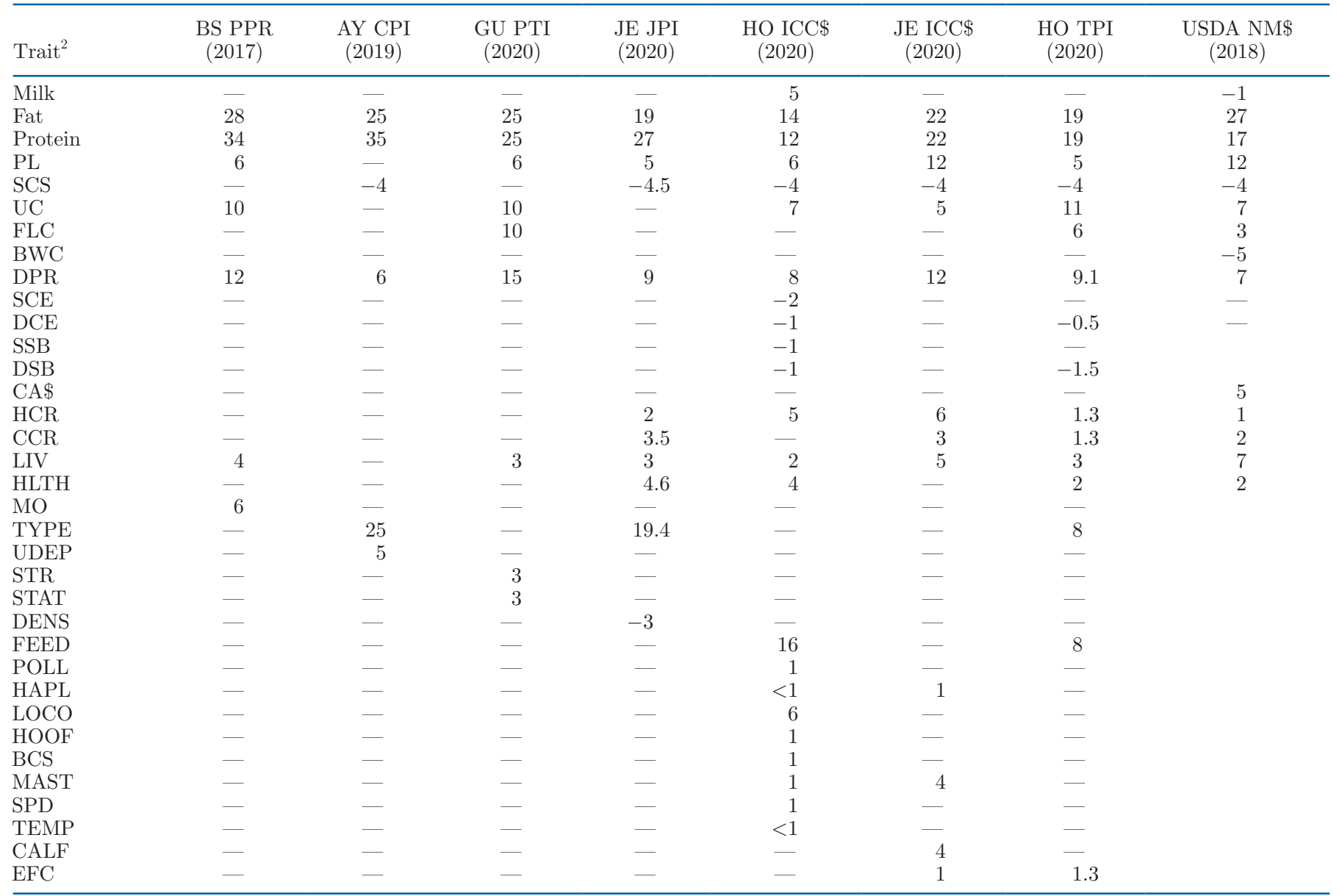

${ }^{1}$ Due to rounding, columns will sometimes sum to a value slightly smaller or larger than 100. BS PPR = Brown Swiss Progressive Performance Ranking (Brown Swiss Association, 2017); AY CPI = Cow Performance Index (US Ayrshire Breeders' Association, 2020); GU PTI = Performance and Type Index (American Guernsey Association, 2020); JE JPI = Jersey Performance Index (Tauchen, 2020); HO ICC $\$=$ Ideal Commercial Cows for Holsteins (Genex, 2020a,b); JE ICC\$ = Ideal Commercial Cows for Jerseys (Genex, 2020a,b); HO TPI = Total Performance Index (Holstein Association USA, 2020); USDA NM\$ = Net Merit Dollars (VanRaden et al., 2018).

${ }^{2} \mathrm{PL}=$ productive life; $\mathrm{UC}=$ udder composite (varies by breed and index); FLC = feet and legs composite; BWC = body weight composite; DPR $=$ daughter pregnancy rate; $\mathrm{SCE}=$ sire (direct) calving ease; $\mathrm{DCE}=$ daughter (maternal) calving ease; $\mathrm{CA} \$=$ calving ability dollars; $\mathrm{HCR}=$ heifer conception rate; $\mathrm{CCR}=\mathrm{cow}$ conception rate; $\mathrm{LIV}=$ cow livability; HLTH $=$ health traits (varies by breed and index); $\mathrm{MO}=$ mobility (Brown Swiss); TYPE = type (conformation) composite (varies by breed); UDEP = udder depth; STR $=$ strength; STAT $=$ stature; DENS = milk density; FEED = feed intake/feed cost (varies by breed and index); SSB = sire (direct) stillbirth; DSB = daughter (maternal) stillbirth; $\mathrm{POLL}=$ polled status; HAPL $=$ haplotypes affecting fertility; $\mathrm{LOCO}=$ locomotion; $\mathrm{HOOF}=$ hoof health; MAST $=$ clinical mastitis; $\mathrm{SPD}=$ milking speed; TEMP = milking temperament; CALF = calf survivability; $\mathrm{EFC}=$ early first calving (age at first calving).

increases in rates of inbreeding are more likely driven by gains in selection intensity as a result of genomic technology (García-Ruiz et al., 2016). The short generation intervals and high rates of gain in each generation have driven seedstock producers to sample heavily within lines that have already produced successful bull families. Each company has limited resources for identifying elite animals, and the risk of losing market share to a competitor is greater now than it was under traditional progeny testing programs because of the speed with which genetic gains accumulate. This is probably why the decline in the rate of inbreeding under genomic selection predicted by Daetwyler et al. (2007) has not materialized - no large AI company is willing to risk sampling largely from outcross families. Even if there was a market for outcross bulls, most phenotypes are collected from daughters of popular families, and prediction accuracies will be lower for the outcross animals. However, the long-term value of broadening the genetic base may be worth the sacrifice of some short-term accuracy. This is similar to the trade-off between changes in inbreeding and rates of genetic gain made in optimal contribution theory (Clark et al., 2013). 
Table 3. Hypothetical composition of a future lifetime Net Merit index that is the sum of subindices for production (PRO\$), longevity (LON\$), fertility (FER $\$)$, type (conformation; TYP\$), calving ability $(\mathrm{CA} \$)$, and health $(\mathrm{HTH} \$)^{1}$

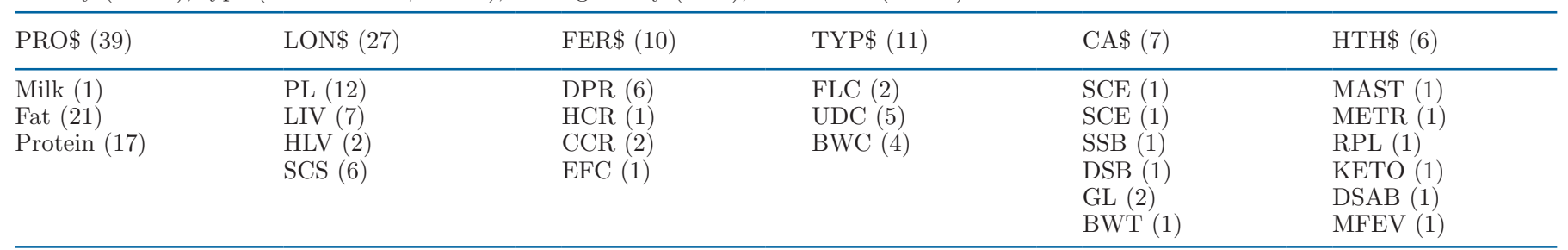

${ }^{1} \mathrm{PL}=$ productive life; $\mathrm{BWC}=$ body weight composite; UDC $=$ udder composite; FLC $=$ feet and legs composite; DPR $=$ daughter pregnancy rate; $\mathrm{SCE}=$ sire (direct) calving ease; $\mathrm{DCE}=$ daughter (maternal) calving ease; $\mathrm{SSB}=$ sire (direct) stillbirth; DSB $=$ daughter (maternal) stillbirth; HCR $=$ heifer conception rate; $\mathrm{CCR}=$ cow conception rate; LIV = cow livability; GL = gestation length; RFI = residual feed intake; $\mathrm{MFV}=$ milk fever (hypocalcemia); DAB = displaced abomasum; KET = ketosis; MAS = clinical mastitis, MET $=$ metritis; RPL $=$ retained placenta; $\mathrm{EFC}=$ early first calving.

It also is possible that the proliferation of indices could lead to the development of more strains within the Holstein breed, with greater inbreeding within each strain but greater diversity overall when crossing strains. Such schemes are similar to breeding strategies proposed for nucleus herd programs (e.g., Meuwissen, 1998), although they are more common in the swine and poultry sectors. Some breeding companies offer mating schemes based on the assignment of young sires to genetic lines within the breed (e.g., Select Sires Inc., 2020), although the manner in which bulls are assigned to lines is not clear.

\section{What Will US Indices Look Like in the Future?}

In many ways, 2021 is a critical year in the evolution of US selection indices. The number of traits evaluated continues to increase, and is overwhelming to many, which suggests that new ways to group and express traits may be needed. The planned addition of feed saved to NM\$ (Council on Dairy Cattle Breeding, 2020) will heighten tensions between economic value and trait reliability, and might make it impossible to continue publishing a single index for use by all breeds. If producers begin to question the credibility of the index, then they may turn to commercial indices developed by AI companies or, in the case of larger farms, develop their own custom tool for ranking animals for selection.

Adoption of Subindices. As the number of traits included in selection indices continues to grow, there is growing interest in constructing $\mathrm{NM} \$$ as the sum of subindices, which Cole and VanRaden (2018) discussed in some detail. The idea is straightforward: instead of presenting an index composed of all traits of economic importance to farmers, biologically similar traits are grouped together into subindices that represent the expected portion of an individual's $\mathrm{NM} \$$ due to their genetic merit for that set of traits. The total merit index is thus the sum of the subindices. The principal advantage of this approach is that it permits breeders to focus on groups of traits that are important, such as cow health, without the need to focus on the individual details of each trait. For example, Table 3 shows a hypothetical version of $\mathrm{NM} \$$ that is constructed as the sum of 6 subindices: production, longevity, fertility, type, calving ability, and health. This example includes some traits that are not currently included in NM\$ (heifer livability and gestation length), and the weights are strictly speculative, but it demonstrates how the focus shifts from individual traits to functionally similar groups of traits. Feed intake might initially be grouped with the production traits, but if additional efficiency traits are added, such as methane or carbon dioxide production, a sustainability subindex could be created. Although grouping traits into subindices would be a new approach for NM\$, the Total Performance Index (Holstein Association USA, 2020) has been constructed using this strategy for many years.

Can We Continue to Use the Same Index Across All Breeds? Historically, USDA has used the same selection index weights for all breeds. When a phenotype is not available for a breed, such as calving traits in Jersey, a value of 0 is assigned to that trait when the index is computed. This means that the relative emphasis each trait receives in the index varies by breed (Table 4), which may not be obvious from the technical documentation (e.g., VanRaden et al., 2018). There is no reranking within breeds because all animals receive the same value for the traits that are not evaluated, but as the differences between breeds grow, the index weights will no longer be optimal. In theory, there should be a breed-specific version of each index for each breed, which would result in 24 indices in place of the current 4.

This problem is likely to increase in magnitude due to the planned addition of feed saved (FS) to the indices, which will have a large economic value (VanRaden et al., 2017) and relatively low reliability compared with 
many other traits (Tempelman and $\mathrm{Lu}, 2020$ ). In addition to affecting the overall reliability of the indices, it has the potential to shift the realized selection differentials if breeds other than Holstein receive a value of 0 for FS. Such distortions would not simply reduce the perceived utility of the indices, but they could affect bull rankings and, therefore, mating decisions. In that case, there would be additional value in switching from $\mathrm{NM} \$$ to a breed-specific index.

Is There a Role for Customized Indices? National selection indices are necessarily based on the assumption that incomes and expenses are similar for all farmers. This may have been true when farms were similar to each other in terms of size and management, but there are now considerable interactions of herd size with herd management. For example, $55.3 \%$ of small herds (30-99 cows) are conventional confinement dairies and $5.1 \%$ are grazing operations, but large herds $(500+$ cows $)$ are $93.8 \%$ conventional and $0.7 \%$ grazing (USDA, 2014). In addition to these differences in feeding and management, some farms also have income streams related to the sale of elite genetics (as embryos or calves) or the production of certified organic prod- ucts. Given such diversity, it is understandable that some farmers might prefer an index tailored to their individual situation.

Customized indices at the farm level were first delivered by McGilliard and Clay (1983), who developed a software tool for selecting groups of bulls to meet individual farm-level goals. Bowman et al. (1996) developed customized indices for Australian dairy farmers, but they were not widely adopted. In addition to the growth in the number of indices discussed earlier, there is growing interest in customized indices at the farm level (Dickrell, 2017). Many farms today have access to powerful computers and broadband or cellular internet, providing them with the ability to transfer data and perform calculations on the farm, although broadband access still lags in many rural areas (Federal Communications Commission, 2018). Some dairies have been taking advantage of access to these tools to develop their own selection objectives. For example, North Florida Holsteins (Bell, Florida) is a 10,000-cow dairy that uses its own custom index to rank bulls for breeding (D. Bennink, North Florida Holsteins, Bell, FL; personal communication). Their index places more

Table 4. Traits included in the lifetime Net Merit index on a breed-specific ${ }^{1}$ versus all-animals basis

\begin{tabular}{lllllll}
\hline Trait & AY & BS & GU & HO & JE & MS \\
\hline Milk & $\mathrm{X}$ & $\mathrm{X}$ & $\mathrm{X}$ & $\mathrm{X}$ & $\mathrm{X}$ & $\mathrm{X}$ \\
Fat & $\mathrm{X}$ & $\mathrm{X}$ & $\mathrm{X}$ & $\mathrm{X}$ & $\mathrm{X}$ & $\mathrm{X}$ \\
Protein & $\mathrm{X}$ & $\mathrm{X}$ & $\mathrm{X}$ & $\mathrm{X}$ & $\mathrm{X}$ & $\mathrm{X}$ \\
PL & $\mathrm{X}$ & $\mathrm{X}$ & $\mathrm{X}$ & $\mathrm{X}$ & $\mathrm{X}$ & $\mathrm{X}$ \\
SCS & $\mathrm{X}$ & $\mathrm{X}$ & $\mathrm{X}$ & $\mathrm{X}$ & $\mathrm{X}$ & $\mathrm{X}$ \\
BWC & $\mathrm{X}$ & $\mathrm{X}$ & $\mathrm{X}$ & $\mathrm{X}$ & $\mathrm{X}$ & $\mathrm{X}$ \\
UDC & $\mathrm{X}$ & $\mathrm{X}$ & $\mathrm{X}$ & $\mathrm{X}$ & $\mathrm{X}$ & $\mathrm{X}$ \\
FLC & $\mathrm{X}$ & $\mathrm{X}$ & $\mathrm{X}$ & $\mathrm{X}$ & $\mathrm{X}$ & - \\
DPR & - & $\mathrm{X}$ & - & $\mathrm{X}$ & - & - \\
SCE & - & $\mathrm{X}$ & - & $\mathrm{X}$ & - & - \\
DCE & - & - & - & $\mathrm{X}$ & - & - \\
SSB & - & - & - & $\mathrm{X}$ & $\mathrm{X}$ & $\mathrm{X}$ \\
DSB & $\mathrm{X}$ & $\mathrm{X}$ & $\mathrm{X}$ & $\mathrm{X}$ & $\mathrm{X}$ & $\mathrm{X}$ \\
HCR & $\mathrm{X}$ & $\mathrm{X}$ & $\mathrm{X}$ & $\mathrm{X}$ & $\mathrm{X}$ & $\mathrm{X}$ \\
CCR & $\mathrm{X}$ & $\mathrm{X}$ & $\mathrm{X}$ & $\mathrm{X}$ & - & - \\
LIV & - & - & - & $\mathrm{X}$ & $\mathrm{X}$ & - \\
GL & - & - & - & $\mathrm{X}$ & $\mathrm{X}$ & - \\
RFI & - & - & - & $\mathrm{X}$ & $\mathrm{X}$ & - \\
MFV & - & - & - & $\mathrm{X}$ & $\mathrm{X}$ & - \\
DAB & - & - & - & $\mathrm{X}$ & $\mathrm{X}$ & - \\
KET & - & - & $\mathrm{X}$ & $\mathrm{X}$ & $\mathrm{X}$ & - \\
MAS & MET & - & - & $\mathrm{X}$ & $\mathrm{X}$ \\
RPL & EFC & - & - & - & $\mathrm{X}$ & - \\
\hline
\end{tabular}

${ }^{1} \mathrm{AY}=$ Ayrshire; $\mathrm{BS}=$ Brown Swiss; GU = Guernsey; HO = Holstein; JE = Jersey; MS = Milking Shorthorn. ${ }^{2} \mathrm{PL}=$ productive life; $\mathrm{BWC}=$ body weight composite; UDC = udder composite; FLC = feet and legs composite; $\mathrm{DPR}=$ daughter pregnancy rate; $\mathrm{SCE}=$ sire (direct) calving ease; $\mathrm{DCE}=$ daughter (maternal) calving ease; SSB = sire (direct) stillbirth; DSB = daughter (maternal) stillbirth; HCR = heifer conception rate; CCR = cow conception rate; $\mathrm{LIV}=$ cow livability; $\mathrm{GL}=$ gestation length; $\mathrm{RFI}=$ residual feed intake; $\mathrm{MFV}=$ milk fever (hypocalcemia); DAB = displaced abomasum; KET = ketosis; MAS = clinical mastitis; MET = metritis; $\mathrm{RPL}=$ retained placenta; EFC $=$ early first calving. 
emphasis on fertility, productive life, udders, and mobility than does $\mathrm{NM} \$$, reflecting the perceived effects of those traits on profitability in that herd. However, some farmers may describe tools used to rank animals (customized indices) and the rules that assign bulls to cows for individual breedings (custom mating programs) as customized indices, and thus there is a need for continued educational efforts.

There is an extensive body of scientific literature focused on the process of allocating bulls to cows for mating (Allaire, 1980; Jansen and Wilton, 1985; Kinghorn, 1998, 2011; Weigel and Lin, 2000; Pryce et al., 2012; Sun et al., 2013; Cole, 2015). Many AI companies provide mating recommendations to their customers as part of their services, but the algorithms used are usually very simple and focus principally on minimization of inbreeding. Mate allocation tools that can accommodate traits with intermediate optima or nonlinear economic values may be of greater value to farmers than customized selection indices. Herd-level strategies also can accommodate individual preferences relating to uniformity or diversity among cows (e.g., Santos et al., 2019).

\section{OPPORTUNITIES AND CHALLENGES}

\section{What About the Environment?}

What Can We Gain by Adding Environmental Effects to Genetic Effects? One of the core assumptions underlying genetic improvement programs is the maxim "P $=\mathrm{G}+\mathrm{E}$," which tells us that the phenotype $(\mathrm{P})$ that we observe is the sum of both genetic $(\mathrm{G})$ and environmental (E) effects (e.g., Falconer and MacKay, 1996). Although a selection index focuses specifically on genetic effects through its prediction of an individual's aggregate breeding value, there is growing interest among farmers in improved predictions that include both genetic and environmental components. Environmental effects are further divided into permanent (e.g., geographic location) and temporary (e.g., a particular ration formulation) components. Temporary effects are very difficult to model because data are very limited, but permanent effects can be modeled and used to support decision-making. For example, most probable producing ability adds permanent environmental effects to estimates of additive genetic merit to provide estimates of an individual's phenotypic performance (e.g., Chyr et al., 1979).

Dunne et al. (2018) recently used best linear unbiased estimates (BLUE) of environmental and management effects to determine effects of herd-level factors on fertility, milk yield, and survival in Irish dairy cattle. Eight herd-level characteristics were assigned to quintiles by year, and a multiple-regression analysis was used to associate differences in BLUE with differences in herd performance. Their results showed, for example, that $21.75 \%$ of the improvement in calving interval was due to genetic selection, and $67.89 \%$ was due to herd-level factors. These results are of interest because BLUE are already calculated as part of routine genetic evaluations, and they may be useful for identifying both favorable and unfavorable changes in herdlevel performance over time. Interest in better tools for on-farm decision support is growing (e.g., Ferris et al., 2020), and BLUE have potential value for that purpose at little additional cost.

There is much speculation - with little data to support it as yet - that the new on-farm sensors can support precision estimates of animal performance that include information about an animal's genotype and details about the specific environment in which the animal is located. These new systems may actually produce estimates of temporary environmental effects, such as a change in disease state, that are extremely variable. It is not clear that such estimates can improve probable producing abilities, but they may be valuable for identifying animals that need closer human attention.

Genotype-by-Environment Interactions. The selection indices used in the United States have always assumed that all animals are performing in the same environment. Although this clearly is not true (e.g., Bohmanova et al., 2008), reranking of bulls when models include heat stress effects is generally small (Wright and VanRaden, 2015), and the observed effects may be related to herd-level factors other than only climate (Zwald et al., 2003). There are some major challenges associated with the collection of environmental data that must be overcome to develop better tools. For example, Misztal (2017) noted that genetic evaluations for resistance to heat stress are confounded with the use of on-farm heat-abatement technologies, which are not reported through the milk recording system. If more detailed information about cow environments was available, then differences between environments could be accounted for in the genetic evaluation models. Discussion with stakeholders at all levels of the dairy production chain are ongoing about the collection of much-more-complete information about the farm environment, such as detailed descriptors of feeding, housing, and milking systems.

\section{New Technologies, New Participants, and New Pipelines}

High-Throughput Phenotyping. It is a wellknown principle in genetic improvement programs that 
the phenotype is the driver of population improvement (Coffey, 2020). New technologies are enabling the largescale collection of novel phenotypes, such as milk composition and animal behavior, often in real-time (Cole et al., 2020). Although such high-throughput phenotyping has been a feature of plant improvement programs for several years (e.g., Fahlgren et al., 2015), it is still in its early stages in livestock production systems (Koltes et al., 2019). Many of these new devices generate data that lack a validated interpretation because their assumptions are not necessarily backed up by direct data on the biological phenomena that they are supposed to represent. However, there will be growing demand from dairy farmers to include these data sources in genetic evaluation programs as the available technologies grow in number and increase in utility.

Why Do the Sources of Data Matter? As the cost of data collection continues to decrease and the volume continues to increase, it is reasonable to ask if data sources matter. Why not accept any data into the national database that farmers want to provide? After all, storage is cheap and the cost of data generation is borne by individual producers, not the genetic evaluation center! This is not as practical as it appears for many reasons, including animal identification, data quality standardization and certification, the presence of data silos, and uncertainty about ownership. The latter issue is not as straightforward as it might seem because farmers do not always own the data stored in their on-farm computer systems, and thus cannot necessarily grant permission for its use even if they have the tools to deposit them in a remote database.

One of the great strengths of the national milk recording system is that it is able to link individual animals with the samples collected from those animals through the use of unique, permanent identification numbers. Many new on-farm sensor systems make use of abbreviated cow control numbers that are recycled over time and are not unique across herds. Although genomic information can be used to identify and correct errors in pedigrees (Nani et al., 2020), it does not currently link samples with the source animal.

Milk recording organizations, such as the NDHIA in the United States, provide quality certification services to ensure that laboratory measurements are accurate and calculations performed on the data are correct (e.g., Quality Certification Services, Inc., 2020). The methods used to test samples and incorporate the resulting observations into genetic improvement and herd management systems have been validated in the scientific literature for many years (e.g., McCaffree et al., 1974; Wiggans and Grossman, 1980; Wiggans and Powell, 1980), and national milk recording systems are the bedrock of our genetic improvement programs. The CDCB has developed a comprehensive program to certify genomic nominators and genotyping laboratories to ensure the accuracy and uniformity of all records included in the national genomic evaluation system (Carillo et al., 2019), and genotypes are accepted only from certified companies. In addition, the International Bull Evaluation Service (Philipsson et al., 1986) provides guidelines for comparing dairy sire evaluations across countries and provides data validation services for its members, and the International Committee for Animal Recording develops guidelines for data collection and genetic evaluation (International Committee for Animal Recording, 2020). Such oversight and standards do not currently exist for many new phenotyping technologies, such as mid-infrared spectral observations and mobility data.

Observations collected from new on-farm systems, such as feed intake or greenhouse gas monitoring units, are typically stored in a proprietary software system provided by the vendor. It can be difficult, expensive, or impossible to get data out of those individual systems and into the on-farm management software that typically ties into milk recording programs. Producers may be surprised to learn that they do not own data generated on their farms from their animals (Ellixson et al., 2018), a situation also faced by early adopters of human-focused devices (Hummel et al., 2020). For example, some agreements specify that farmers are provided with access to data generated by a system, but that ownership remains with the vendor. There is a system in place for certifying that crop companies comply with certain principles with respect to farm data (Ag Data Transparent, 2020), but there is not currently an equivalent framework in place for dairy data. The International Dairy Data Exchange Network (https://www.idden.org/) is a newly formed organization that facilitates data exchange between dairy equipment manufacturers and dairy industry members, and it may become an important conduit for moving data between different systems.

Tension Among Commercial and Scientific Interests. As discussed above, FS as a trait has very high economic value but relatively low reliabilities because of the small number of records available. Due to the current high cost of recording the amount of feed consumed by cows each day, it is unlikely that the reliability of FS will improve very much. From the scientific point of view, this is not necessarily of great importance because it is not a methodological problem, per se. The calculation of new index weights remains a relatively straightforward task regardless of the reliabilities of the traits in the index. However, there is the 
potential for tension between commercial and scientific groups because each has different priorities from the other. The scientific question is one of correct methodology; however, commercial entities are faced with the challenge of making sales in a highly competitive marketplace where high reliabilities are important for marketing purposes and are required for access to some international markets. The addition of FS to $\mathrm{NM} \$$ with a high weight, which is driven by the costs associated with feeding dairy cows, is going to reduce the overall reliability of the index, perhaps substantially. This is challenging because there may be strong pressure from breeding companies to reconsider the assumptions used to compute the index. The response from the scientific community may seem simple, but intransigence may lead to a lack of confidence in the index or the development of additional proprietary tools. A framework for this conversation currently exists, as shown in Figure 1 and discussed previously, but it would be a mistake to assume that these will be easy conversations with quick outcomes.

It is clear from the literature that selection index methodology will deliver optimal profitability in the long run. However, there is risk associated with the selection process for AI companies because breeding for long-term objectives affects short-term profitability. The tension between short-term gain and long-term risk could be addressed by classifying indices according to some measure of risk, which would enable decision-makers to select the index that best represents the trade-offs they are willing to make. However, the literature is limited in this area (Rogers, 1990; Woolliams and Meuwissen, 1993; Huirne et al., 1997) and additional research will be needed to develop suitable tools for assessing the long-term risk associated with breeding goals.

\section{What Is Needed to Meet the Challenges of Tomorrow?}

To retain its position as a global leader in genetic improvement, the US dairy industry must meet several challenges as markets continue to evolve and farm demographics change. This requires a focus on principles rather than organizations, which may be in conflict with the dairy industry's trend toward greater consolidation that more closely resembles the closed model of swine and poultry breeding than the historical openness of dairy evaluations. Genetic evaluation should be structured as a precompetitive service in which data are collected and calculations performed by a precompetitive entity. Methods are public to allow for peer review and open debate to ensure their technical correctness, and all data are treated consistently. Product differentiation is a downstream function; for example, an AI company might construct its own selection index to meet specific needs of its customers by using predicted transmitting abilities calculated in the national evaluation, or farmers may use edited genotypes from their cows in a mating program. It is likely that some companies will continue to develop proprietary evaluations as a matter of competitive advantage, but they are likely to have lower reliabilities than national evaluations and may not represent random samples of the cow population. Genetic evaluations are most effective when they are treated as a shared resource, but there is room for tremendous innovation in how those evaluations are used to make decisions. The routine introduction of evaluations for new traits by individual companies suggests that there is still incentive for them to invest in data collection.

The erosion of positions dedicated to dairy extension has resulted in the replacement of experts tasked with the objective transfer of information from scientists to farmers, and has resulted in the widespread use of consultants and agribusiness representatives to advise farmers (Bernard, 2019). This challenge is not unique to the United States (Murphy et al., 2013); farmers everywhere need independent information that can be used to solve problems, but it is increasingly difficult to find. It is perhaps easy to dismiss the dearth of extension specialists with the comment that there are plenty of other experts out there, but that overlooks the issue of objective knowledge transfer versus commercial pressures.

\section{CONCLUSIONS}

In the past, selection decisions were made by famers with input from trusted advisors. Sources of information were limited and generally understood by industry participants. Changes were gradual, providing time for people to adapt at a comfortable pace. There are now many sources of information, often lacking independent or continuous validation, and their value is not always clear. The rate of change is rapid, and farmers need objective sources of information more than ever before. The best way for the industry to meet the needs of the dairy producers, who drive the whole system, is to treat genetic evaluations as a shared good for the benefit of all.

\section{ACKNOWLEDGMENTS}

J. B. Cole was supported by appropriated project 8042-31000-002-00-D, "Improving Dairy Animals by Increasing Accuracy of Genomic Prediction, Evaluating New Traits, and Redefining Selection Goals," of 
the Agricultural Research Service (ARS) of the United States Department of Agriculture (USDA; Washington, DC). Mention of trade names or commercial products in this article is solely for the purpose of providing specific information and does not imply recommendation or endorsement by the US Department of Agriculture. The USDA is an equal opportunity provider and employer. The authors have not stated any conflicts of interest. Two anonymous reviewers are thanked for their constructive feedback, which helped to improve the quality of this manuscript.

\section{REFERENCES}

Ag Data Transparent. 2020. Ag Data's Core Principles. Accessed Sept. 1, 2020. https://www.agdatatransparent.com/principles.

Allaire, F. R. 1980. Mate selection by selection index theory. Theor. Appl. Genet. 57:267-272. https://doi.org/10.1007/BF00264953.

American Guernsey Association. 2020. Genetic Information. Accessed Aug. 21, 2020. https://www.usguernsey.com/pedigree-system.

Bernard, J. K. 2019. Invited review: Dairy extension programs in the southern region: Finding novel ways to meet the needs of our producers. Appl. Anim. Sci. 35:1-7. https://doi.org/10.15232/aas .2018-01781.

Berry, D. P., P. R. Amer, R. D. Evans, T. Byrne, A. R. Cromie, and F. Hely. 2019. A breeding index to rank beef bulls for use on dairy females to maximize profit. J. Dairy Sci. 102:10056-10072. https:/ /doi.org/10.3168/jds.2019-16912.

Binversie, J. 2019. Choosing the Index That Meets Your Dairy's Needs. Accessed Aug. 20, 2020. https://www.progressivedairy .com/topics/a-i-breeding/choosing-the-index-that-meets-your -dairy-s-needs.

Bohmanova, J., I. Misztal, S. Tsuruta, H. D. Norman, and T. J. Lawlor. 2008. Short communication: genotype by environment interaction due to heat stress. J. Dairy Sci. 91:840-846. https://doi.org/ $10.3168 / j d s .2006-142$.

Bowman, P. J., P. M. Visscher, and M. E. Goddard. 1996. Customized selection indices for dairy bulls in Australia. Anim. Sci. 62:393403. https://doi.org/10.1017/S1357729800014946.

Brown Swiss Association. 2017. Progressive Performance Ranking. Accessed Aug. 21, 2020. https://www.brownswissusa.com/Breed/ Genetics/PPRFormula/tabid/312/Default.aspx.

Byrne, T. J., B. F. S. Santos, P. R. Amer, D. Martin-Collado, J. E. Pryce, and M. Axford. 2016. New breeding objectives and selection indices for the Australian dairy industry. J. Dairy Sci. 99:81468167. https://doi.org/10.3168/jds.2015-10747.

Cameron, N. D. 1997. Selection Indices and Prediction of Genetic Merit in Animal Breeding. CAB International.

Carillo, J., G. Wiggans, E. Nicolazzi, K. Tokuhisa, D. Norman, and J. Dürr. 2019. CDCB's genotyping laboratory certification program. Interbull Bull. 55:58-63.

Chyr, S.-C., A. E. Freeman, and J. Berger. 1979. Estimation of milk producing ability of Holstein cows. J. Dairy Sci. 62:1774-1783. https://doi.org/10.3168/jds.S0022-0302(79)83496-7.

Clark, S. A., B. P. Kinghorn, J. M. Hickey, and J. H. van der Werf. 2013. The effect of genomic information on optimal contribution selection in livestock breeding programs. Genet. Sel. Evol. 45:44. https://doi.org/10.1186/1297-9686-45-44.

Coffey, M. 2020. Dairy cows: In the age of the genotype, \#phenotypeisking. Anim. Front. 10:19-22. https://doi.org/10.1093/af/ vfaa004.

Cole, J. B. 2015. A simple strategy for managing many recessive disorders in a dairy cattle breeding program. Genet. Sel. Evol. 47:94. https://doi.org/10.1186/s12711-015-0174-9.

Cole, J. B., S. A. E. Eaglen, C. Maltecca, H. A. Mulder, and J. E. Pryce. 2020. The future of phenomics in dairy cattle breeding. Anim. Front. 10:37-44. https://doi.org/10.1093/af/vfaa007.
Cole, J. B., and P. M. VanRaden. 2018. Symposium review: Possibilities in an age of genomics: The future of selection indices. J. Dairy Sci. 101:3686-3701. https://doi.org/10.3168/jds.2017-13335.

Council on Dairy Cattle Breeding. 2020. Feed Saved (FSAV) Trait Reference Sheet. Accessed Feb. 25, 2021. https://www.uscdcb .com/wp-content/uploads/2020/11/CDCB-Reference-Sheet-Feed -Saved-12_2020.pdf.

Daetwyler, H. D., B. Villanueva, P. Bijma, and J. A. Woolliams. 2007. Inbreeding in genome-wide selection. J. Anim. Breed. Genet. 124:369-376. https://doi.org/10.1111/j.1439-0388.2007.00693.x.

De Vries, A. 2020. Symposium review: Why revisit dairy cattle productive lifespan? J. Dairy Sci. 103:3838-3845. https://doi.org/10 .3168/jds.2019-17361.

Dechow, C. D. 2020. Do Indexes Actually Predict Profitability? Accessed Aug. 20, 2020. https://hoards.com/article-28360-do-indexes -actually-predict-profitability.html.

Dickinson, F. N., B. T. McDaniel, and H. D. Norman. 1971. USDADHIA Sire Summary List, May 1971. USDA Agricultural Research Service.

Dickrell, J. 2017. Build Your Own Sire Index. Accessed Aug. 14, 2017. http://www.dairyherd.com/magazine/build-your-own-sire-index.

Dunne, F. L., M. M. Kelleher, S. W. Walsh, and D. P. Berry. 2018 Characterization of best linear unbiased estimates generated from national genetic evaluations of reproductive performance, survival, and milk yield in dairy cows. J. Dairy Sci. 101:7625-7637. https:/ /doi.org/10.3168/jds.2018-14529.

Ellixson, A., T. Griffin, S. Ferrell, and P. Goeringer. 2018. Legal and Economic Implications of Farm Data: Ownership and Possible Protections. Social Science Research Network. Accessed Mar. 3 2021. http://agecon.okstate.edu/faculty/publications/6029.pdf.

Fahlgren, N., M. A. Gehan, and I. Baxter. 2015. Lights, camera, action: High-throughput plant phenotyping is ready for a close-up. Curr. Opin. Plant Biol. 24:93-99. https://doi.org/10.1016/j.pbi .2015.02.006.

Falconer, D. S., and F. C. MacKay. 1996. Introduction to Quantitative Genetics. Longman.

Federal Communications Commission. 2018. 2018 Broadband Deployment Report. Federal Communications Commission.

Ferris, M. C., A. Christensen, and S. R. Wangen. 2020. Symposium review: Dairy Brain - Informing decisions on dairy farms using data analytics. J. Dairy Sci. 103:3874-3881. https://doi.org/10.3168/ jds.2019-17199.

Fessenden, B., D. J. Weigel, J. Osterstock, D. T. Galligan, and F. Di Croce. 2020. Validation of genomic predictions for a lifetime merit selection index for the US dairy industry. J. Dairy Sci. 103:1041410428. https://doi.org/10.3168/jds.2020-18502.

Freeman, A. E. 1984. Secondary traits: Sire evaluation and the reproductive complex. J. Dairy Sci. 67:449-458. https://doi.org/10 .3168/jds.S0022-0302(84)81324-7.

García-Ruiz, A., J. B. Cole, P. M. VanRaden, G. R. Wiggans, F. J. Ruiz-López, and C. P. Van Tassell. 2016. Changes in genetic selection differentials and generation intervals in US Holstein dairy cattle as a result of genomic selection. Proc. Natl. Acad. Sci. USA 113:E3995-E4004. https://doi.org/10.1073/pnas.1519061113.

Gay, K. D., N. J. O. Widmar, T. D. Nennich, A. P. Schinckel, J. B. Cole, and M. M. Schutz. 2014. Development of a Lifetime Meritbased selection index for US dairy grazing systems. J. Dairy Sci. 97:4568-4578. https://doi.org/10.3168/jds.2013-7474.

Genex. 2020a. ICC $\$$ for Holsteins. Accessed Aug. 21, 2020. https:// genex.coop/dairy/icc/icc-holstein/.

Genex. 2020b. ICC $\$$ for Jerseys. Accessed Aug. 21, 2020. https:// genex.coop/dairy/icc/icc-jersey/.

Gjedrem, T. 1972. A study on the definition of the aggregate genotype in a selection index. Acta Agric. Scand. 22:11-16. https://doi.org/ 10.1080/00015127209433456.

Hazel, L. N., G. E. Dickerson, and A. E. Freeman. 1994. The selection index-then, now, and for the future. J. Dairy Sci. 77:3236-3251. https://doi.org/10.3168/jds.S0022-0302(94)77265-9.

Holstein Association USA. 2020. TPI Formula-April 2020. Accessed Aug. 21, 2020. https://www.holsteinusa.com/genetic_evaluations/ ss_tpi_formula.html. 
Huirne, R. B. M., S. B. Harsh, A. A. Dijkhuizen, and S. Bezemer. 1997. Assessing the risk attitude of dairy farmers with respect to income and sire selection. Mansholt Studies. No. 7. Backhuys Publishers, Leiden.

Hummel, P., M. Braun, and P. Dabrock. 2020. Own data? Ethical reflections on data ownership. Philos. Technol. https://doi.org/10 .1007/s13347-020-00404-9.

International Committee for Animal Recording. 2020. ICAR Guidelines. International Committee for Animal Recording.

Jansen, G. B., and J. W. Wilton. 1985. Selecting mating pairs with linear programming techniques. J. Dairy Sci. 68:1302-1305. https: //doi.org/10.3168/jds.S0022-0302(85)80961-9.

Kinghorn, B. P. 1998. Mate selection by groups. J. Dairy Sci. 81:55-63. https://doi.org/10.3168/jds.S0022-0302(98)70154-7.

Kinghorn, B. P. 2011. An algorithm for efficient constrained mate selection. Genet. Sel. Evol. 43:4. https://doi.org/10.1186/1297-9686 $-43-4$.

Koltes, J. E., J. B. Cole, R. Clemmens, R. N. Dilger, L. M. Kramer, J. K. Lunney, M. E. McCue, S. D. McKay, R. G. Mateescu, B. M. Murdoch, R. Reuter, C. E. Rexroad, G. J. M. Rosa, N. V. L. Serão, S. N. White, M. J. Woodward-Greene, M. Worku, H. Zhang, and J. M. Reecy. 2019. A vision for development and utilization of high-throughput phenotyping and big data analytics in livestock. Front. Genet. 10:1197. https://doi.org/10.3389/fgene .2019.01197.

Leitch, H. W. 1994. Comparison of international selection indices for dairy cattle breeding. Interbull Bull. 10:1-7.

Maltecca, C., F. Tiezzi, J. B. Cole, and C. Baes. 2020. Symposium review: Exploiting homozygosity in the era of genomics - Selection, inbreeding, and mating programs. J. Dairy Sci. 103:5302-5313. https://doi.org/10.3168/jds.2019-17846.

Martin-Collado, D., T. J. Byrne, P. R. Amer, B. F. S. Santos, M. Axford, and J. E. Pryce. 2015. Analyzing the heterogeneity of farmers' preferences for improvements in dairy cow traits using farmer typologies. J. Dairy Sci. 98:4148-4161. https://doi.org/10 3168/jds.2014-9194.

McCaffree, J. D., R. W. Everett, H. R. Ainslie, and B. T. McDaniel. 1974. Economic value of dairy herd improvement programs. J. Dairy Sci. 57:1420-1422. https://doi.org/10.3168/jds.S0022 -0302(74) 85077-0.

McGilliard, M. L., and J. S. Clay. 1983. Selecting groups of sires by computer to maximize herd breeding goals. J. Dairy Sci. 66:647653. https://doi.org/10.3168/jds.S0022-0302(83)81839-6.

Meuwissen, T. H. E. 1998. Optimizing pure line breeding strategies utilizing reproductive technologies. J. Dairy Sci. 81:47-54. https:/ /doi.org/10.3168/jds.S0022-0302(98)70153-5.

Miglior, F., A. Fleming, F. Malchiodi, L. F. Brito, P. Martin, and C. F. Baes. 2017. A 100-Year Review: Identification and genetic selection of economically important traits in dairy cattle. J. Dairy Sci. 100:10251-10271. https://doi.org/10.3168/jds.2017-12968.

Miglior, F., B. L. Muir, and B. J. Van Doormaal. 2005. Selection indices in Holstein cattle of various countries. J. Dairy Sci. 88:12551263. https://doi.org/10.3168/jds.S0022-0302(05)72792-2.

Misztal, I. 2017. Breeding and Genetics Symposium: Resilience and lessons from studies in genetics of heat stress. J. Anim. Sci. 95:1780-1787. https://doi.org/10.2527/jas.2016.0953.

Murphy, C., R. Nettle, and M. Paine. 2013. The evolving extension environment: Implications for dairy scientists. Anim. Prod. Sci. 53:917-923. https://doi.org/10.1071/AN12347.

Nani, J. P., L. R. Bacheller, J. B. Cole, and P. M. VanRaden. 2020. Discovering ancestors and connecting relatives in large genomic databases. J. Dairy Sci. 103:1729-1734. https://doi.org/10.3168/ jds.2019-17580.

Norman, H. D. 1986. Sire evaluation procedures for yield traits. USDA Ext. Serv.

Norman, H.D., B.G. Cassell, F.N. Dickinson, and A.L. Kuck. 1979. USDA-DHIA milk components sire summary. USDA Prod. Res. Rep.

Norman, H. D., and F. N. Dickinson. 1971. An economic index for determining the relative value of milk and fat in predicted dif- ferences of bulls and cow index values of cows. DHI Lett. USDA Agricultural Research Service.

Norman, H. D., J. R. Wright, and R. H. Miller. 2010. Response to alternative genetic-economic indices for Holsteins across 2 generations. J. Dairy Sci. 93:2695-2702. https://doi.org/10.3168/jds .2009-2499.

Philipsson, J., G. Banos, and T. Arnason. 1994. Present and future uses of selection index methodology in dairy cattle. J. Dairy Sci. 77:3252-3261. https://doi.org/10.3168/jds.S0022-0302(94)77266 -0 .

Philipsson, J., B. Danell, L. R. Schaeffer, M. Schneeberger, H. SchulteCoerne, and J. B. M. Wilmink. 1986. Procedures applied at present for conversion of sire proofs. Interbull Bull. 1:5-11.

Philipsson, J., and B. Lindhé. 2003. Experiences of including reproduction and health traits in Scandinavian dairy cattle breeding programmes. Livest. Prod. Sci. 83:99-112. https://doi.org/10.1016/ S0301-6226(03)00047-2.

Pryce, J. E., B. J. Hayes, and M. E. Goddard. 2012. Novel strategies to minimize progeny inbreeding while maximizing genetic gain using genomic information. J. Dairy Sci. 95:377-388. https://doi.org/10 $.3168 /$ jds.2011-4254.

Quality Certification Services, Inc. 2020. Auditing Guidelines. Accessed Sept. 1, 2020. http://www.quality-certification.com/ guidelines.asp.

Rogers, G. W. 1990. A utility function for ranking sires that considers production, linear type traits, semen cost, and risk. J. Dairy Sci 73:532-538. https://doi.org/10.3168/jds.S0022-0302(90)78700-0.

Santos, D. J. A., J. B. Cole, T. J. Lawlor Jr., P. M. VanRaden, H. Tonhati, and L. Ma. 2019. Variance of gametic diversity and its application in selection programs. J. Dairy Sci. 102:5279-5294. https://doi.org/10.3168/jds.2018-15971.

Schmidt, M. 2020. Breeding for the Post-COVID-19 Cow. Accessed Aug. 20, 2020. https://www.progressivedairy.com/topics/a-i -breeding/breeding-for-the-post-covid-19-cow.

Schmitt, M. R., P. M. VanRaden, and A. De Vries. 2019. Ranking sires using genetic selection indices based on financial investment methods versus lifetime net merit. J. Dairy Sci. 102:9060-9075. https:/ /doi.org/10.3168/jds.2018-16081.

Select Sires Inc. 2020. StrataGEN. Accessed Nov. 16, 2020. https:// www.selectsires.com/genetics/programs/stratagen.

Shook, G. E. 2006. Major advances in determining appropriate selection goals. J. Dairy Sci. 89:1349-1361. https://doi.org/10.3168/jds .S0022-0302(06)72202-0.

Sun, C., P. M. VanRaden, J. R. O'Connell, K. A. Weigel, and D. Gianola. 2013. Mating programs including genomic relationships and dominance effects. J. Dairy Sci. 96:8014-8023. https://doi .org/10.3168/jds.2013-6969.

Tauchen, K. 2020. Learning More About JPI 2020. Accessed Aug. 21, 2020. https://usjerseyjournal.com/learning-more-about-jpi-2020/.

Tempelman, R. J., and Y. Lu. 2020. Symposium review: Genetic relationships between different measures of feed efficiency and the implications for dairy cattle selection indexes. J. Dairy Sci. 103:53275345. https://doi.org/10.3168/jds.2019-17781.

U.S. Ayrshire Breeders' Association. 2020. Genetics/Breed Leaders. Accessed Aug. 21, 2020. http://www.usayrshire.com/genetics .html.

USDA. 2014. Dairy 2014, Dairy Cattle Management Practices in the United States, 2014. USDA-APHIS-VS-CEAH-NAHMS.

VanRaden, P. M. 2000. AIPL Research Report NM\$1 (11-00): Net Merit as a Measure of Lifetime Profit - 2000 Version. Accessed Apr. 7, 2020. https://aipl.arsusda.gov/reference/nmcalc-2000.htm.

VanRaden, P. M. 2004. Invited review: Selection on net merit to improve lifetime profit. J. Dairy Sci. 87:3125-3131. https://doi.org/ 10.3168/jds.S0022-0302(04)73447-5.

VanRaden, P. M., J. B. Cole, and K. L. Parker Gaddis. 2018. AIP Research Report NM\$7 (5-18): Net Merit as a Measure of Lifetime Profit: 2018 Revision. Accessed Apr. 7, 2020. https://aipl.arsusda .gov/reference/nmcalc-2018.htm.

VanRaden, P. M., and G. R. Wiggans. 1995. Productive life evaluations: Calculation, accuracy, and economic value. J. Dairy Sci. 78:631-638. https://doi.org/10.3168/jds.S0022-0302(95)76674-7. 
VanRaden, P.M., J.R. Wright, E.E. Connor, M.J. VandeHaar, R.J. Tempelman, J.S. Liesman, L.E. Armentano, and K.A. Weigel. 2017. Preliminary genomic predictions of feed saved for 1.4 million Holsteins. J. Dairy Sci. 100(Suppl. 2):200-201. (Abstr.)

Weigel, K. A., and S. W. Lin. 2000. Use of computerized mate selection programs to control inbreeding of Holstein and Jersey cattle in the next generation. J. Dairy Sci. 83:822-828. https://doi.org/ 10.3168/jds.S0022-0302(00)74945-9.

Wiggans, G. R., J. B. Cole, S. M. Hubbard, and T. S. Sonstegard. 2017. Genomic selection in dairy cattle: The USDA experience. Annu. Rev. Anim. Biosci. 5:309-327. https://doi.org/10.1146/ annurev-animal-021815-111422.

Wiggans, G. R., and M. Grossman. 1980. Computing lactation records from sample-day production. Dairy Herd Improv. Lett. 56:1-6.

Wiggans, G. R., and R. L. Powell. 1980. Projection factors for milk and fat lactation records. Dairy Herd Improv. Lett. 56:1-15.
Woolliams, J. A., and T. H. E. Meuwissen. 1993. Decision rules and variance of response in breeding schemes. Anim. Sci. 56:179-186. https://doi.org/10.1017/S0003356100021231.

Wright, J. R., and P. M. VanRaden. 2015. Genetic interactions for heat stress and herd yield level: Predicting foreign genetic merit from domestic data. J. Dairy Sci. 98(Suppl. 2):350. (Abstr.)

Zwald, N. R., K. A. Weigel, W. F. Fikse, and R. Rekaya. 2003. Identification of factors that cause genotype by environment interaction between herds of Holstein cattle in seventeen countries. J. Dairy Sci. 86:1009-1018. https://doi.org/10.3168/jds.S0022 -0302(03)73684-4.

\section{ORCIDS}

John B. Cole @ https://orcid.org/0000-0003-1242-4401 